Artikel Konseptual

Submitted: 4 Mei 2019

Accepted: 26 Juni 2019

Published: 30 Juni 2019

\title{
PEMBELAJARAN SEJARAH UNTUK GENERASI Z
}

Widayati Rahayu

Wiwik_sudjarwo@yahoo.com

SMA Negeri 1 Bululawang, Kab. Malang

Abstract: History is a past event which have a meaning if you want to learn from these past experiences. The past events are essentially the most valuable lessons for the next generation. The latest developments in history must be followed for educational purposes, especially the development of knowledge, which in the end is the development of their own historical insights and science, so that history as a science and event and learning history itself can be updated. Education as a process of fostering the nation characterized by various moral, social, economic, political and national identity inequalities. On the other hand the development of science and technology growing fastly to demands the changes and development. Z Generation well known as a character that less focused than millennial, more versatile, more individualized, more global, more open-minded, and more technology-friendly. The birth of Generation Z demands the role of history teacher to always update the ways in learning history.

Keywords: Historical Learning, Z Generation

\section{PENDAHULUAN}

Undang-Undang Nomor 20 Tahun 2003 tentang Sistem Pendidikan Nasional dijelaskan bahwa pendidikan nasional berfungsi mengembangkan kemampuan dan memberikan watak serta peradaban bangsa yang bermartabat dalam rangka mencerdaskan kehidupan bangsa, bertujuan untuk mengembangkan potensi peserta didik agar menjadi manusia yang beriman, bertaqwa kepada Tuhan Yang Maha Esa, berakhlak mulia, sehat, 
berilmu, cakap, kreatif, mandiri, dan menjadi warga negara yang demokratis serta bertanggung jawab (Pasal 3, UU Nomor 20/2003).

Dalam pelaksanaannya pendidikan sebagai proses pembinaan bangsa, masih sangat memprihatinkan. Perkembangan kehidupan masyarakat masih ditandai dengan berbagai ketimpangan moral, akhlak, masalah-masalah sosial, ekonomi, politik dan jati diri bangsa. Inilah problem-problem yang kini banyak mengemuka di Indonesia. Ditambah lagi perkembangan ilmu dan tehnologi yang sangat cepat dan menuntut perubahan dan perkembangan. Sebagai seorang guru sejarah memiliki tanggung jawab yang besar dalam menyelaraskan kemajuan ilmu dan teknologi yang berkembang pesat dengan cara yang harus dilakukan dalam mengajarkan materi sejarah kepada siswanya.

Dalam kenyataan sehari-hari, seringkali muncul keluhan dari siswa-siswa bahwa pelajaran Sejarah itu membosankan, karena fakta-fakta, tahun-tahun, tokoh-tokoh dan seterusnya yang harus dihafalkan. Begitu juga sering kita dengar dari orang awam, bahkan ada juga yang kaum terpelajarpun mengatakan bahwa guru sejarah adalah orang yang pandai bercerita. Barangkali itu ada benarnya, karena dari pengalaman mereka demikian adanya, siswa selalu dijejali dengan seabreg hafalan oleh guru, bukan mengajaknya berpikir tentang peristiwa masa lalu (sejarah). Bagi orang awam, sejarah itu secara konvensional memang berisikan cerita (narasi) masa lalu, tetapi apakah setiap cerita masa lalu dapat dikatakan sejarah? Oleh karena itu di sinilah perbedaan orang awam dan orang yang professional (mempelajari sejarah) dalam memahami cerita masa lalu atau sejarah.

\section{SEJARAH DAN GENERASI Z}

Sejarah merupakan rekonstruksi kehidupan umat manusia ada masa lalu tentang suatu peristiwa dalam dimensi waktu dan tempat (Kuntowijoyo, 1995: 1-17). Oleh karena itu, sejarah harus dinarasikan agar dapat diketahui bagaimana ia dimengerti atau dipahami oleh pembacanya. Jadi sejarah naratif membuat deskripsi tentang masa lampau dengan merekonstruksi apa yang terjadi serta diuraikan sebagai cerita, dengan perkataan lain kejadian-kejadian penting diseleksi dan diatur menurut poros waktu demikian rupa, sehingga tersusun sebagai cerita. Sebaliknya sejarah nonnaratif merupakan peristiwa sejarah yang dianalisis dan dideskripsikan dengan menggunakan pendekatan ilmu-ilmu so- 
sial lebih menitikberatkan pada problem-oriented dengan menggunakan konsep ilmu sosial yang mencoba mengungkap pelbagai tingkat atau dimensi dari realitas sejarah (Sartono Kartodirdjo, 1993: 9). Keduanya sama bercerita tentang masa lampau, hanya saja sejarah nonnaratif cenderung lebih memperluas penelitian kearah masalah-masalah sosial dan ekonomi daripada masalah politik belaka (Sartono Kartodirdjo,1993:9). Dalam hal ini bahwa masing-masing aspek dalam kehidupan manusia itu, sesungguhnya saling mempengaruhi. Oleh karena itu penggunaan ilmu-ilmu sosial sebagai pendekatan sangat diperlukan untuk menganalisis kehidupan masa lampau manusia yang begitu komplet. Hanya dengan berdasarkan perpaduan konsep-konsep dan teori-teori dari ilmu-ilmu sosial dan sejarah dengan metode-metode baru itu dapat diharapkan bahwa keterbatasan sejarah konvensional dapat diatasi (Sartono Kartodirdjo, 1993: 14).

Sebagai peristiwa masa lampau, sejarah menjadi pengalaman (experience) yang akan menimbulkan atau memberi kesadaran bagi orang yang mempelajarinya. Oleh karena itu sejarah bukan hanya pengetahuan, tetapi juga menyangkut kesadaran, "belajarlah dari sejarah" (Taufik Abdullah dan Abdurrahman Surjomihardjo, 1985: ix). Dalam hal ini tentu saja bagaimana mengemas peristiwa masa lampau umat manusia itu ke dalam suatu tulisan menjadi suatu hal yang menarik bagi pembacanya. Pada tataran ini, kemampuan meramu dan menggunakan ilmu bantu sejarah dan pendekatan ilmu sosial sangat dituntut, karena menjadikan peristiwa masa lampau itu menjadi suatu analisis dan cerita yang menarik.

Generasi Z merupakan suatu kelompok orang masih mencari identitas diri, sehingga mereka mudah menerima pengaruh atau unsur-unsur baru dari luar diri dan lingkungannya. Hal itu sudah menjadi ciri khas anak-anak muda. Oleh karena itu mereka ini merupakan suatu kesempatan menjadi objek yang menarik dalam pembentukan karakternya. Namun mereka yang terbentuk itu sangat sedikit sekali dibandingkan dengan populasi seluruhnya.

Generasi Z adalah masa depan bangsa yang diprediksikan puncak kesuksesannya adalah di Indonesia emas tahun 2045. Penting bagi bangsa ini untuk memahami perilaku dan kebiasaan mereka. Generasi Z dikenal sebagai karakter yang lebih tidak fokus dari milenial, lebih serba-bisa, lebih individual, lebih global, berpikiran lebih terbuka, dan lebih ramah teknologi. Saya lebih menyebut Generasi Z adalah genersai internet. Generasi yang serba 'Kilk'

JPSI, Vol. 2, No. 1, 2019 
Kedekatan generasi Z dengan teknologi membuat kehidupan mereka serba terkoneksi dengan internet, bangsa ini harus siap memasuki era baru, saat milenial menua dan generasi Z mulai dewasa. Menuju 100 tahun Indonesia emas permasalahan moral dan kesetiaan terhadap bangsa tampak memprihatinkan. Melalui pembelajaran sejarah diharapkan atmosfer sejarah khususnya keteladanan para pahlawan dapat melahirkan inspirasi positif guna menangkal karakter-karakter yang tidak sejiwa dengan pandangan hidup bangsa yaitu Pancasila.

Dalam pencarian identitas diri, sekurangnya ada tiga lingkungan yang cukup berpengaruh, yaitu lingkungan keluarga, masyarakat dan sekolah. Dalam hal ini terjadi tarik menarik pengaruh di dalam dirinya. Mereka memiliki otoritas untuk memilih mengenai apa yang terbaik menurutnya. Pemenang dari persaingan ini tentu saja yang paling dominan memberi pengaruh, apakah itu positif atau negatif terhadap mereka.

Lingkungan yang dimaksud dalam pembahasan ini adalah lingkungan sekolah. Dimana guru sejarah memiliki peranan penting dan tanggung jawab dalam pembentukan kepribadian generasi Z. Kendatipun setiap generasi dalam masa lampau sangat menentukan perjalanan sejarah bangsa ini, seharusnya mereka bisa belajar peristiwa masa lalu tersebut. Bagaimana kepribadian tersebut ditunjukkan oleh masing-masing generasi dalam memperjuangan bangsanya dan melahirkan ide-ide yang sangat brilian untuk membentuk persatuan bangsa dan negara.

Persoalan lain juga tidak terlepas dari guru sebagai pendidik yang membentuk kepribadian siswanya, generasi $Z$. Tentu saja dalam hal ini guru harus mampu membuat skenario untuk menanamkan nilai-nilai bagi pembentukan kepribadian, sehingga menjadi identitas diri bagi generasi muda. Oleh karena itu, banyak pihak menuntut bahwa status dan peran guru dalam masyarakat begitu penting. Pendidikan yang bermutu hanya bisa diraih jika sekolah memiliki guru-guru bermutu (Koesoema, 2009: ix).

\section{PEMBELAJARAN SEJARAH UNTUK GENERASI Z}

Bagaimanapun juga sejarah itu merupakan narasi atau cerita tentang peristiwa sejarah, apakah itu pemahaman sejarah secara konvensional atau modern. Perbedaan di antara keduanya terdapat pada metode dan pendekatan yang digunakan dalam menganalisis suatu peristiwa. Pada tataran ini tentu saja guru sejarah sebagai tenaga 
profesional harus memiliki kemampuan menjelaskan persoalan tersebut melalui pembelajaran sejarah itu. Perkembangan mutakhir dari ilmu sejarah harus diikuti untuk keperluan terutama pengembangan pengetahuannya sendiri dengan melakukan penelitian-penelitian, yang pada akhirnya adalah pengembangan wawasan dan keilmuan sejarah sendiri, sehingga sejarah sebagai ilmu dan peristiwa serta pengajaran sejarah sendiri dapat di-update.

Dengan demikian pembelajaran sejarah diharapkan tidak lagi sebagaimana telah menjadi pembicaraan dalam masyarakat awam yang selama ini berkembang di tengah masyarakat. Sebagai peristiwa masa lampau, sejarah menjadi pengalaman (experience) yang akan menimbulkan atau memberi kesadaran bagi orang yang mempelajarinya. Oleh karena itu sejarah bukan hanya pengetahuan, tetapi juga menyangkut kesadaran, "belajarlah dari sejarah" (Abdullah \& Surjomihardjo, 1985: ix). Dalam hal ini tentu saja bagaimana mengemas peristiwa masa lampau umat manusia itu ke dalam suatu tulisan menjadi suatu hal yang menarik bagi pembacanya.

Pada tataran ini, kemampuan meramu dan menggunakan ilmu bantu sejarah dan pendekatan ilmu sosial sangat dituntut, karena menjadikan peristiwa masa lampau itu menjadi suatu analisis dan cerita yang menarik. Sebagai peristiwa yang telah berlalu, tentu saja sejarah dianggap oleh masyarakat secara umum 'suatu hal yang tidak up to date', apabila hal itu dipandang dari sudut nilai-nilai yang matrialistis, tetapi jangan lupa bahwa kejadian atau peristiwa masa lampau umat manusia yang dijadikan sejarah itu merupakan yang menentukan untuk masa selanjutnya.

Sebagai contoh peristiwa masa Kolonial, Pergerakan Nasional dengan organisasi pergerakan, dan seterusnya merupakan konsep-konsep yang dibangun dari peristiwaperistiwa sejarah. Semua peristiwa-peristiwa yang lahir pada masa itu dilahirkan dengan secara sadar oleh mereka (tokoh-tokoh) yang sadar akan kehidupan dan nasib bangsanya pada masa itu, sehingga mereka berbuat dan melakukan tindakan-tindakan sesuai dengan kemampuan yang dimilikinya pada waktu itu. Oleh karena itu peristiwa yang terjadi itu merupakan "peristiwa yang disengaja" (Taufik Abdullah dan Abdurrahman Surjomihardjo, 1985: xi-xii) dilakukan oleh pelaku-pelaku sejarah untuk tujuan dan maksudmaksud tertentu, jadi peristiwa itu terjadi bukan secara kebetulan. Belajar dari pengalaman masa lampau baik secara langsung atau melalui tulisan sejarah, para tokoh atau pelaku sejarah secara sadar membuat perencanaan yang lebih baik untuk melakukan tindakan-tindakan selanjutnya. 
Para peneliti, penulis, pengajar sejarah dan peminat sejarah biasanya akan memunculkan pertanyaan, bagaimana peristiwa itu terjadi, mengapa muncul peristiwa itu, dan seterusnya. Jawaban dari pertanyaan itulah melahirkan pengetahuan dan pengalaman baru, serta pelajaran untuk menghadapi kehidupan masa kini dan masa yang akan datang. Sir John Seeley mengatakan bahwa "kita belajar sejarah adalah agar lebih bijaksana pada masa yang akan datang”. Bung Karno juga sering mengatakan kata-kata "jas merah" (jangan sekali-kali melupakan sejarah). Cicero menyatakan bahwa barang siapa tidak mengenal sejarahnya akan tetap menjadi anak kecil (Sartono Kartodirdjo, 1993: 23).

Pernyataan tersebut menunjukkan bahwa peristiwa dan pengalaman masa lalu sangat penting untuk membuat perkiraan, perencanaan serta keputusan untuk masa yang akan datang. Namun banyak orang seringkali lupa bahwa peristiwa masa lampau (sejarah) sangat penting bagi kelanjutan kehidupan masa depannya, sehingga sejarawan mengemukakan bahwa sejarah itu mempunyai tiga dimensi, yaitu masa lampau, masa kini ini, dan masa yang akan datang.

Hal ini dapat kita perhatikan bahwa kealpaan terhadap peristiwa yang pernah menimbulkan petaka pada lampau menyebabkan muncul peristiwa berikutnya yang tidak kurang dahsyatnya dari peristiwa sebelumnya dengan model dan cara-cara yang sama pada masa berikutnya. Persoalan tersebut sudah menjadi suatu hal yang lumrah terjadi, karena dengan begitu saja melupakan dan tidak belajar dari peristiwa sebelumnya. Meskipun dalam berbagai kesempatan seringkali diutarakan bahwa "bangsa yang besar adalah yang tidak melupakan peristiwa masa lalunya", namun hal itu hanya sebatas menjadi pameo, karena tidak menjadi pengalaman atau terinternalisasi, terutama bagi elit yang lebih banyak sebagai pengambil keputusan .

Pembelajaran Sejarah untuk Generasi Z berarti menyampaikan esensi dan hakekat sejarah dengan cara yang lebih 'up to date'. Caranya yang lebih ditekankan, tanpa mengurangi esensi dari fakta sejarah dan peristiwa masa lalu. Seorang guru sejarah harus mengup-date juga cara mengajar mengikuti arah pikiran yang berkembang dari Generasi Z.

\section{PENUTUP}


Sejarah merupakan peristiwa masa lampau, ia akan berarti dan bermakna apabila mau belajar dari pengalaman masa lampau tersebut. Peristiwa masa lampau itu pada hakikatnya adalah pelajaran yang paling berharga bagi generasi selanjutnya, karena ia menyajikan berbagai pengalaman yang pernah terjadi dan ada pada masa lampau. Pengalaman tersebut tidaklah diputus bagi generasi berikutnya, karena hal itu akan menyebabkan generasi penerusnya akan kehilangan jati dirinya sebagai suatu bangsa.

Di sinilah dituntut para guru sejarah dalam bidang pengajaran sejarah harus mampu membuat pembelajaran sejarah menjadi pelajaran yang diminati. Oleh karena itu, pelajaran sejarah harus menjadi pembelajaran menggunakan ranah Bloom pada tingkat tinggi, tidak lagi hanya pembelajaran pada tingkat recall (menghafalkan fakta-fakta saja) tanpa suatu makna yang didapatkan dari suatu peristiwa sejarah.

\section{DAFTAR PUSTAKA}

Kuntowijoyo. (1995). Pengantar Ilmu Sejarah. Yogyakarta.

Gottschalk, L. (1969). Mengerti Sejarah. Jakarta: UI Press.

Kartodirdjo, S. (1993). Pendekatan Ilmu-ilmu Sosial dalam Metodologi Sejarah. Jakarta: Gramedia Pustaka Utama

Abdullah, T. dan Surjomihardjo, A. (1985). Ilmu Sejarah dan Historiografi: Arah dan Perspektif. Jakarta: PT Gramedia

Undang-Undang Nomor 20 Tahun 2003 tentang Sistem Pendidikan Nasional 